\title{
Geo-Spatial Database Creation for Wazirabad Canal Command Area
}

\author{
Chalumuri Ramesh Naidu", M. V. S. S. Giridhar \\ Jawaharlal Nehru Technological University Hyderabad, Hyderabad, India \\ E-mail: ${ }^{*}$ chrnaidu@rediffmail.com \\ Received April 17, 2011; revised May 29, 2011; accepted June 17, 2011
}

\begin{abstract}
GIS assist in specific planning and decision-making processes in irrigation through the input, spatial analysis and output of relevant information. The real strength of GIS is its ability to integrate information. This integration power makes the scope of GIS almost infinite. The unique integration capability of GIS allows disparate data sets to be brought together to create a complete picture of a situation. GIS technology illustrates relationships, patterns and connections that are not necessarily obvious in any one data set but are amazingly apparent once the data sets are integrated. GIS also helps us to assess the performance of the irrigation command areas. GIS based system helps a canal to analyze the spatial information about its engineers and farmers to improve planning, management and supply of water resources to its corresponding blocks. In order to manage the water efficiently in the command area, it is needless to say that calculation and evaluation of water demands in detail at block and minor level to be given overriding priority. Blocks and Chak boundaries can be delineated from the Digital Elevation Model using GIS techniques. These boundaries will help to plan and allocate the water resources to improve the water allocation strategies and in turn water use efficiency and can make inter-canal comparisons. The delineated block boundaries can be refined exactly using the drainage, topography and existing canal network in GIS platform.
\end{abstract}

Keywords: GIS, Command Area, Block, Chak

\section{Introduction}

Most of the major irrigation command areas [1] in India suffer from problems of inadequate and unreliable water supply having wide gaps between irrigation [2] potential created and utilized. This study area is influencing lack of regular evaluation of system performances [3,4] and working knowledge about proper water management due to lack of spatially related information about the command area and canal network system [5]. The available hard copy maps are not to scale and there is no integration between the maps for evaluation. The water allocation in command area is defined by the blocks and chaks. These blocks are controlled by Water Users Associations [6]. To evaluate the water allocation and usage with respect to actual or theoretical water demand, delineation of block boundaries are essential. Geographical Information System (GIS) [7] produces the terrain maps at his location accuracy and containing detailed information of the variables under study. GIS $[7,8]$ are databases that usually have a spatial component to the storage and processing of the data. Hence, they have the potential to both store and create map like products. They also offer the potential for performing multiple analysis or evaluation of scenarios in different applications.

Development of Geospatial database [9] and Decision Support System $[10,11]$ for Irrigation command areas is important to achieve several objectives in planning the land and water resources. Several studies were done for large command areas in a regional scale using the GIS technology and performance of the canal systems $[12,13]$. But hardly there are any attempts made in analyzing the micro level command areas using GIS in assessing the water demand and water use efficiency. This paper is a part of $\mathrm{PhD}$ thesis and highlights the methodology of mapping [13] canal block and chak boundaries for attaining the main objective for efficient use of water in irrigating the crops.

\section{Study Area}

The selected Wazirabad Command Area (Figure 1) is in 


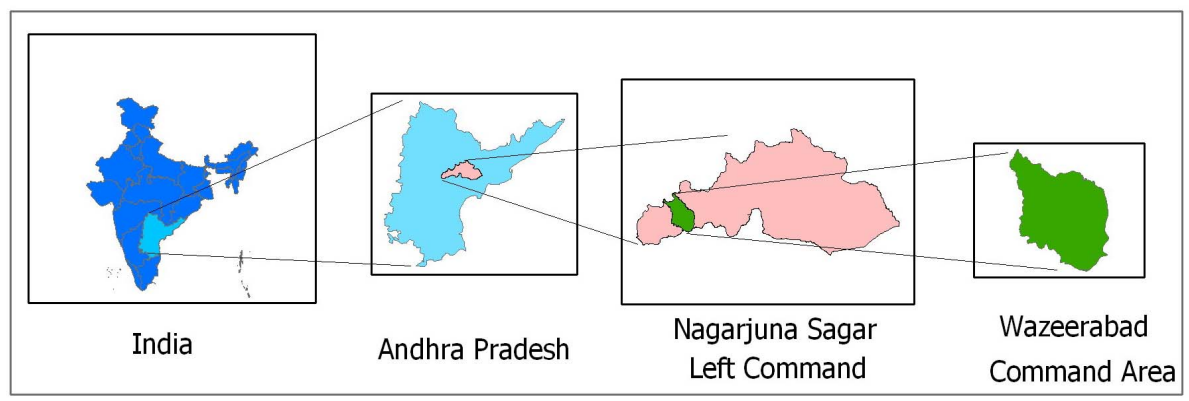

Figure 1. Study Area.

Zone.I under block No.5 of Left Main Canal in Nagarjunasagar Project (NSP). It is located between $16^{\circ} 39 ' 2.84^{\prime \prime}$ and $16^{\circ} 56^{\prime} 40.81^{\prime \prime} \mathrm{N}$ latitude and $79^{\circ} 25^{\prime} 16.01^{\prime \prime}$ and $79^{\circ} 40^{\prime} 52.90^{\prime \prime} \mathrm{E}$ longitude. Mirialguda is the nearest town connected by ground road network. The total extent of command area is 26,700 hectares. The study area is located flat and medium undulating terrain with maximum and minimum elevation ranging between 187 and $44 \mathrm{~m}$ above MSL. The area experiences semi-arid climatic conditions and receives an average annual rainfall about $750 \mathrm{~mm}$. In general, the slope of the command area is towards east. The maps available with the irrigation department

\section{Methodology}

Canal Network is digitized and delineated using the Survey of India (SOI) topo maps of scale 1:25,000.

Block and Chak boundaries were delineated from the features resulted from surface modeling tools, topo map and digitized canal network. The digitized canal network data, Block and Chak boundaries were converted to GIS Database to calculate the irrigated areas [14] for achieving the further scope of the thesis. DEM is generated using the collected contour map from Irrigation Department. The Methodology is represented in Figure 2

The following layers are generated in GIS Platform:

- Canal line;

- Canal Node;

- Contour and Digital Elevation Model;

- Command Area Boundary including Block and Chak; boundary;

The GIS Data incorporates the following information on different layers which is illustrated in Table $\mathbf{1}$ and the list of softwares used for creation of database in Table 2.

The following layers are generated in GIS Platform:

Canal line;

Canal Node;

Soil Map;

Contour and Digital Elevation Model;

Command Area Boundary including Block and chak; boundary.

The methodology illustrates in the following sections.

\subsection{Collection of Input}

The data includes:

- SOI topo maps are also collected from the Survey of India for reference;

- Existing Block maps and other collateral data concerned command area;

- Contour Map.

\subsection{Scanning and Georeferencing of Topo Maps, and Block Maps}

The existing topo maps and block maps are scanned in 400 dpi and imported in Erdas Imagery in .img format. Geo-referencing is done using Erdas software. Scanned maps are imported in .img format and geo-referenced to one or sub pixel accuracy with respect to the Ground Control Points collected from both SOI map and Block Maps. These Control points are locations that can be accurately identified on the Block maps and in SOI Topo Maps. These identifiable locations may be road and stream intersections, building corners, bridges, the mouth of a stream, rock outcrops etc. These control points are used to build a polynomial transformation that warps the Block maps from one coordinate space to another.

All coordinates and residuals are reported in latitude, longitude and height as per the following Projection $\mathrm{Pa}$ rameters:

- Projection: Universal Transverse Mercator (UTM);

- Horizontal Datum: World Geodetic System (WGS);

- Zone 44.

\subsection{Canal Network Database Creation}

The irrigation water is originated from Nagarjunasagar Dam and is distributed through left and right main canal. For the study area water is diverted from the left main canal (a point spatial feature) and flows through the 


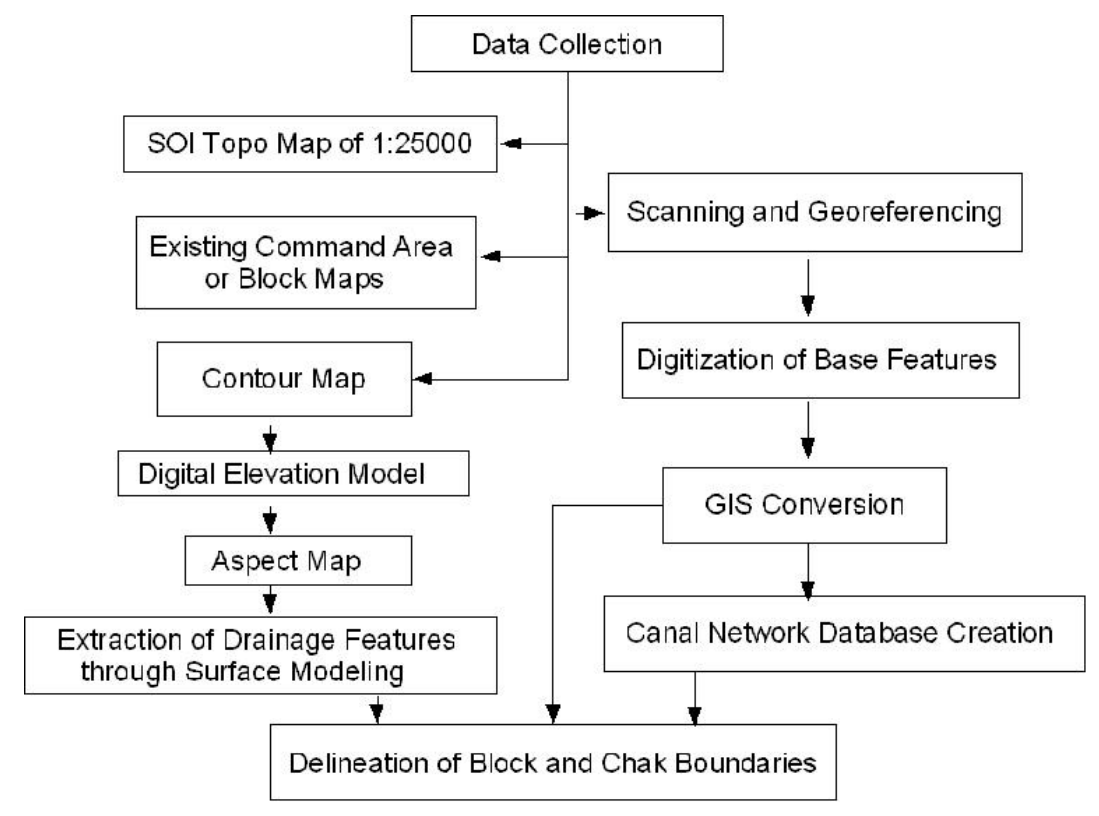

Figure 2. Methodology.

Table 1. List of layers, scale and source of the data.

\begin{tabular}{|c|c|c|c|c|c|}
\hline S. No & Layer & Attribute Data & Theme & Scale & Source \\
\hline 1 & Canal Line & $\begin{array}{l}\text { Start node, Endnote, } \\
\text { XCOORD, YCOORD, } \\
\text { Length, type, ID, } \\
\text { Discharge }\end{array}$ & Line & $1: 25,000$ & SOI Topo map \\
\hline 2 & Canal Node & $\begin{array}{l}\text { Start node, Endnote, } \\
\text { XCOORD, YCOORD, } \\
\text { Length, type, ID, Eleva- } \\
\text { tion, Discharge }\end{array}$ & Point & $1: 25,000$ & SOI Topo map \\
\hline 3 & Contour & ID, Elevation & Polygon & $1 \mathrm{~m}$ & Block Maps from NSP \\
\hline 4 & DEM & $1 \mathrm{~m}$ & Raster & $1 \mathrm{~m}$ & From generated contour map \\
\hline 5 & Aspect Map & $1 \mathrm{~m}$ & Raster & $1 \mathrm{~m}$ & From generated DEM \\
\hline 6 & $\begin{array}{c}\text { Command Area Boundary } \\
\text { including Block and Chak } \\
\text { Boundary }\end{array}$ & $\begin{array}{l}\text { Block ID, Chak ID, } \\
\text { Area, Canal ID }\end{array}$ & Polygon & $1: 25,000$ & $\begin{array}{l}\text { Topo map and Existing } \\
\text { Command area maps from } \\
\text { Irrigation Department, and } \\
\text { DEM }\end{array}$ \\
\hline
\end{tabular}

Table 2. List of software used.

\begin{tabular}{|c|c|c|}
\hline S. NO & Task & Software \\
\hline 1 & $\begin{array}{c}\text { Scanning and Georeferencing of Topomaps } \\
\text { Mosaicing of Topo Maps } \\
\text { DEM and Aspect }\end{array}$ & Erdas Imagine and GRASS GIS \\
\hline 2 & Digitization and Updation of Base Features & Auto CAD \\
\hline 3 & $\begin{array}{c}\text { Editing and Transformation of Digitized Data } \\
\text { GIS Database Creation and Linking } \\
\text { Map Composition } \\
\text { Reports }\end{array}$ & ArcGIS and ArcInfo \\
\hline 4 & Non-Spatial Database & MS Access, Excel \\
\hline
\end{tabular}

major and minor canal network (line spatial features) and finally to the farms (polygon spatial features). The canal network data structure is important to assess the spatial distribution of the water demand and supply for the irrigation planning and management.

The data was prepared in a network module which 
constitutes nodes and lines. The node data refers to Sluice OT and line refers to canal. The flow direction and continuity errors were taken care while digitization and later checked for continuity in the ArcGIS Network Module.

The canal ID is created with a unique multi digit number constitutes a combination of alphabets and numbers. All canal reaches have only one upstream reach but have more than one downstream reaches. Only the upstream reach ID is kept for each sections in the developed data system. The hierarchic relationship can be retrieved through the use of Upper id.

\subsection{Creation of Contour Map, Digital Elevation Model (DEM) and Aspect Map}

Digital representations of the terrain often form one of the main elements of the mapping process. Digital Elevation Model (DEM) [15] represents continuous variation of topography over space that helps in assessing landscape characteristics and has a wide application in surface hydrology modeling. These characteristics help to determine slope, flow directions, areas, boundaries and outlets of drainage basins and ultimately in delineating the Block and Chak boundaries for this study. Using GRASS GIS the DEM is generated.

Contours are digitized from the Block maps collected from the Irrigation Department. These contours used as an elevation data for creating the Digital Elevation Model. The DEM is used as an input for creating the Aspect Map.

\subsection{Delineation of Command Area, Block and Chak Boundaries}

The delineation is based on surface modeling techniques available in many GIS and Remote Sensing [16] Techniques. GRASS Software is used for doing the surface modeling. One of the most sophisticated GIS capabilities which are very useful in hydrographic modeling is the digital representation of the topography of the catchments. Surface modeling is a general term which is used to describe the process of representing a physical or artificially created surface by means of a mathematical expression. Terrain modeling is one particular category of surface modeling which deals with the specific problems of representing the surface of the earth. The techniques of terrain modeling are of widespread use and have been app1ied widely in the physical and earth sciences.

The DEM [16] provides 3D [16] input data for calculating flow direction across terrain, which is subsequently used for creation of stream networks. Delinea- tion of surface Hydrology Features from DEM data has become standardized on the eight-direction pour point model in which each cell is connected to one of its eight neighbor cells (four on the principal axes, four on the diagonals) according to the direction of steepest descent. Given an elevation grid, a grid of flow directions is constructed, and from this is derived a grid of flow accumulation, counting the number of cells upstream of a given cell. Streams are identified as lines of cells whose flow accumulation exceeds a specified number of cells and thus a specified upstream drainage area. Extracted stream lines obtained with this give us general information about the characteristic of terrain.

The Chaks and Block Boundaries under each canal are delineated reference to canal network, DEM, Aspect and drainage network extracted from surface modeling and SOI Topo maps. The Chaks are mapped as per the type of canal and its flow direction. If the canal is a ridge canal Chaks are identified on both sides of it and if it is a contour canal Chaks are on one side only. Spread of a Chak is between the canal and the drainage line.

\section{Results and Reports}

The canal network with line and nodes are represented in Figure 3. The canal network is overlaid on DEM and the the streams and valleys are extracted from the hydraulic model. The canals and streams are combined together to form block and chak boundaries are shown in Figure 4. There are 13 canals mapped in network model and including major canal and under each canal the sub-blocks and chaks are identified with reference to DEM and identified topographic features. Canal and corresponding sub-block are coded with same identification code. Chaks under each sub-block are prefixed with canal and the corresponding sub-block id.

The gross command area under each block under each canal and the lengths of the canals are given in Table 3. The command area under WL2 Canal is shown in Figure 5 using spatial query.

The gross command area of each chak under an individual block i.e. WR6 is shown in Table 4.

The delineated block boundaries are compared with the existing block maps. The measurements of block areas and canal lengths in GIS are matching with the statistics given by the irrigation department. The GIS database found very useful in identification of canals and corresponding block and chak boundaries. Due to the hierarchy and the unique identity of block and chak under each canal the spatial queries and retrieval of data and results are more convenient for decision making and planning of water releases for effective water management [17]. 


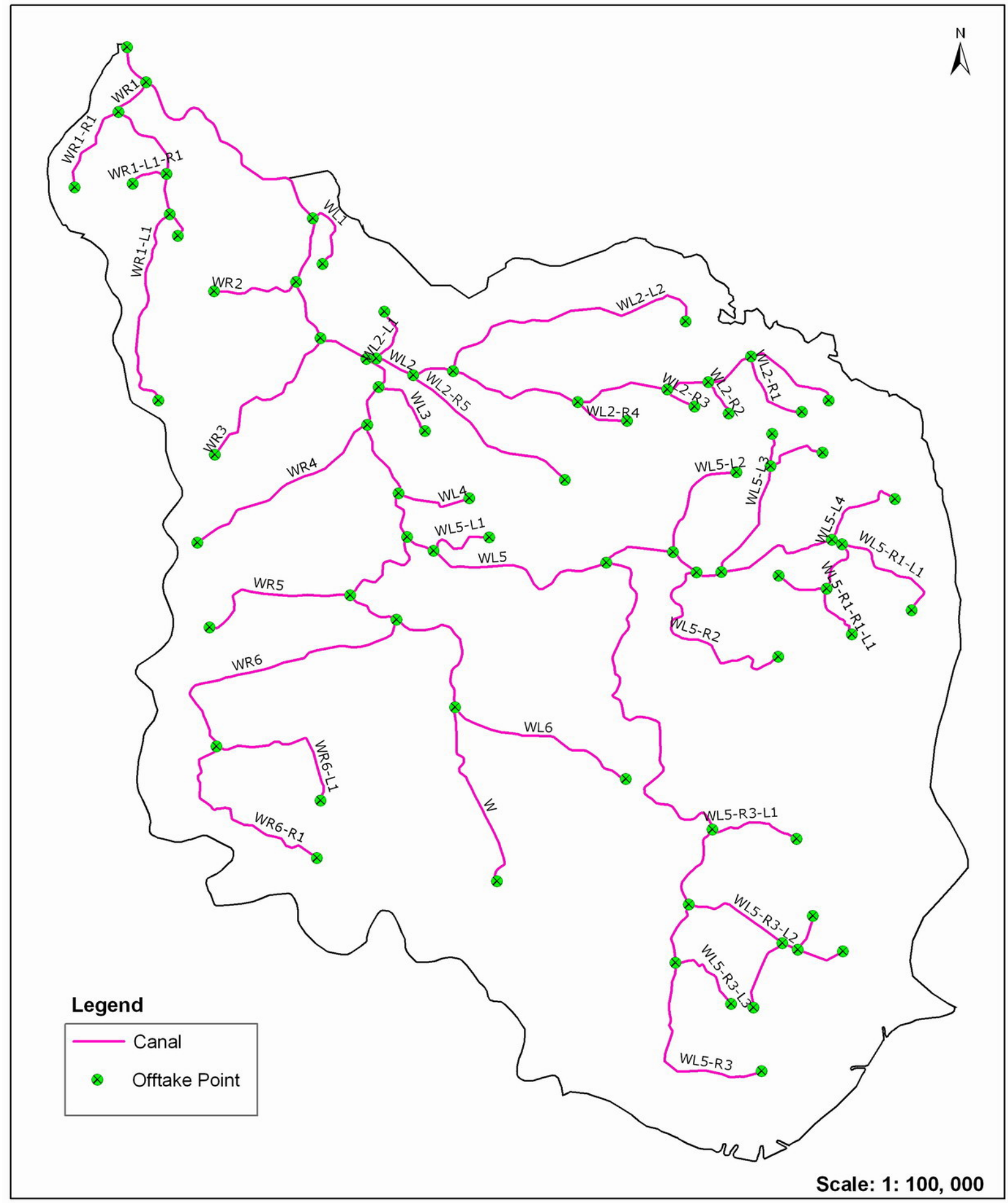

Figure 3. Canal network representing line and nodes.

\section{Conclusions}

GIS plays an important role in Irrigation management. It is necessary to develop a geospatial database that provides sufficient information for Irrigation experts and Water Resources managers. 


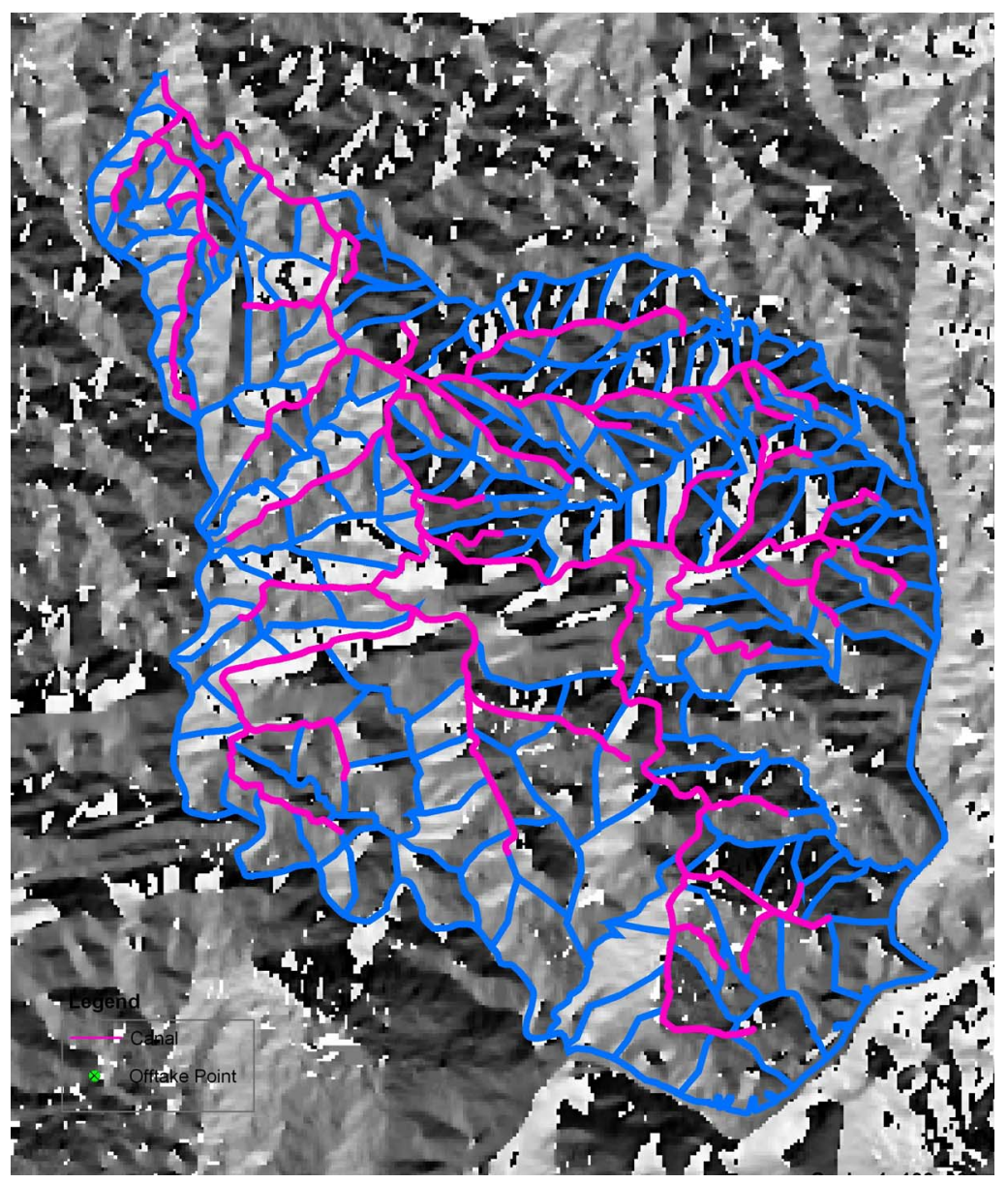

Figure 4. Canal blocks and chaks from digital elevation model.

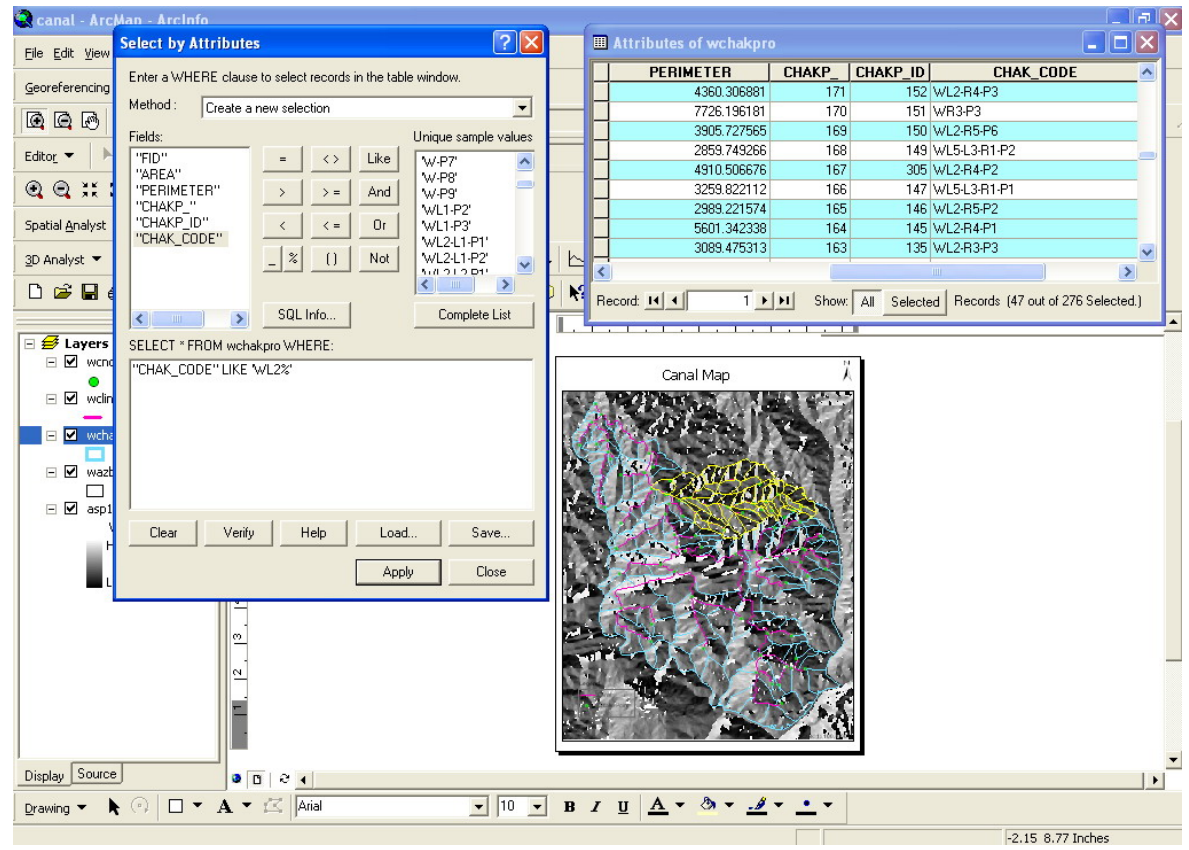

Figure 5. Command area under canal WL2 using spatial query. 
Table 3. Canal and block-wise gross command area statistics.

\begin{tabular}{ccccc}
\hline S. No & Canal-Id & Sub-block & Length(M) & Gross Command Area in Square. Metres \\
\hline 1 & WX & WX & 24956.76 & 32421489.156 \\
2 & WL1 & WL1 & 1496.46 & 2888445.532 \\
3 & WL2 & WL2 & 26457.68 & 34349697.839 \\
4 & WL3 & WL3 & 1492.82 & 2094636.229 \\
5 & WL4 & WL4 & 1581.59 & 2943784.722 \\
6 & WL5 & WL5 & 57093.04 & 77214212.748 \\
7 & WL6 & WL6 & 4049.10 & 10736690.313 \\
8 & WR1 & WR1 & 11427.41 & 11857393.828 \\
9 & WR2 & WR2 & 1897.11 & 3835936.438 \\
10 & WR3 & WR3 & 3650.75 & 7118706.768 \\
11 & WR4 & WR4 & 4473.04 & 7128574.473 \\
12 & WR5 & WR5 & 3486.65 & 8036570.211 \\
13 & WR6 & WR6 & 13784.47 & 21412738.698 \\
\hline
\end{tabular}

Table 4. Chak-wise gross command area under a single block.

\begin{tabular}{ccc}
\hline S. No & Chak-Code & Area in Square Metres \\
\hline 1 & WR6-R1-P2 & 379046.6622 \\
2 & WR6-R1-P3 & 730550.3533 \\
3 & WR6-R1-P4 & 1803694.482 \\
4 & WR6-R1-P5 & 553659.0395 \\
5 & WR6-L1-P3 & 2402665.42 \\
6 & WR6-R1-P1 & 1516726.059 \\
7 & WR6-R1-P6 & 2102915.284 \\
8 & WR6-L1-P5 & 1039530.989 \\
9 & WR6-L1-P4 & 1679120.628 \\
10 & WR6-L1-P2 & 2049298.493 \\
11 & WR6-P1 & 1094497.439 \\
12 & WR6-L1-P1 & 3951621.478 \\
13 & WR6-P2 & 859442.5685 \\
14 & WR6-P3 & 1249969.803 \\
WR6 & Total & $\mathbf{2 1 4 1 2 7 3 8 . 7}$ \\
\hline
\end{tabular}

GIS has capability to assess and plan the water resources in efficient way. This data is developed for detailed analysis in arriving water demands for chaks under each canal up to minor canal.

\section{Acknowledgements}

The authors are highly grateful to aarvee associates, Hyderabad, JNTU, Hyderabad and Irrigation Department, NSLC, Mirialaguda for encouragement and providing basic infrastructure, inputs and facilities for the study.

\section{References}

[1] G. Vimal and S. Ritu, "Designing Decision Support Systems to aid Irrigation Water Planning and Management in Command Areas," 6th Annual International Conference,
Geospatial Communication, India, 2003.

[2] T. H. Rao, "Design of Irrigation Carrier Systems to Meet Tail-End Area Requirements,” Technical Report, Articles on Jalayagnam, Andhra Pradesh.

[3] W. Ojeda-Bustamantea, J. M. González-Camachob, E. Sifuentes-Ibarrac and E. Isidroa, "Using Spatial Information Systems to Improve Water Management in Mexico," Agricultural Water Management, Vol. 89, No. 1-2, pp. 81-88. doi:10.1016/j.agwat.2006.11.002

[4] W.-T. Lin, Y.-F. Ho and M.-D. Su, "GIS for Irrigation Management in Irrigation Associations,” FAO Irrigation and Drainage Papers, Rome.

[5] Y. Labye, "Design and Optimization of Irrigation Distribution Networks,” FAO Irrigation and Drainage Papers, Vol. 44, Rome.

[6] D. E. Nelson, "Performance Indicators for Irrigation Canal System Managers or Water Users Associations,” 18th 
International Congress on Irrigation and Drainage, Montréal, Vol. 1B, pp. 1-12.

[7] P. S. Roy and V. V. Rao, "Water Resources Development: Remote Sensing Technology Perspective-Remote Sensing and GIS-Water Management,” Indo-US Workshop on Innovative E-technologies for Distance Education and Extension for Efficient Water Management, ICRISAT, Patancheru/Hyderabad, 5-9 March 2007.

[8] A. Sarangi, N. H. Rao, S. M. Brownee and A. K. Singh, "Use of Geographic Information System (GIS) Tool in Watershed Hydrology and Irrigation Water Management," Indo-US Workshop on Innovative E-technologies for Distance Education and Extension/Outreach for Efficient, ICRISAT, Patancheru/Hyderabad, 5-9 March 2007.

[9] C. Nguyen and L. Dang, "A Geospatial Database for Vietnam Lao and Cambodia," Pharaohs to Geoinformatics, FIG Working Week 2005 and GSDI-8, Cairo, 16-21 April 2005.

[10] M. A. Sharifi, "Integrated Planning and Decision Support Systems for Sustainable Watershed Development," Watershed Development Organized by Asian Productivity Organization \& The Iranian Ministry of Agriculture, Tehran, 12-17 October 2002.

[11] T. B. S. Rajput, "Decision Support System for Efficient Water Management in Canal Command Areas by B.
Krishna Rao,” Indian Academy of Sciences, Bangalore.

[12] R. K. Nema, N. Dubey and M. K. Awasthi, "RS \& GIS Approach for Evaluation of Irrigation Status," Conference Drainage and Irrigation Water Management, pp. 204-213.

[13] G. C. Mouli, "Mapping the Features of an Irrigation Project for Performance Assessment," Map World Forum 2009.

[14] Technical Innovations, AP Water Reforms, Irrigation and Command Area Development, "Satellite Remote Sensing Based Estimating of Irrigated Area,” Vol. 51, pp. 25-39.

[15] N. Dubey, R. K. Nema, M. K. Awasthi, Y. K. Tiwari, "Digital Elevation Model (DEM) for Patan Branch Canal Command Area Using RS and GIS,” Command Area Development and Management 2005, pp. 136-141.

[16] A. Razzak, T. Ziboon and A. N. Mohsin, "3D Virtual Maps Production for Mosul City by Using GIS Techniques,” Journal of Engineering Technology, Vol. 27, No. 9, 1987.

[17] B. K. Rao and T. B. S. Rajput, "Decision Support System for Efficient Water Management in Canal Command Areas,” Current Science, Vol. 97, No. 1, 2009, p. 90. 